\title{
Methodical approaches to energy supply with usage of renewable energy sources on objects of transport infrastructure of federal importance
}

\author{
Vyacheslav Shestakov ${ }^{1}$, Olga Novikova $^{1, *}$, Artem Melnichenko ${ }^{1}$, and Anastasia \\ Luchnikova $^{1}$ \\ ${ }^{1}$ Peter the Great St. Petersburg Polytechnic University, 29 Politekhnicheskaya street, 195251, Saint \\ Petersburg, Russia.
}

\begin{abstract}
In this article we consider the potential possibility of using renewable energy sources for the construction of transport infrastructure facilities of the Federal importance. We analyzed major promising projects for the construction of roads and bridges for the period until 2030 year, considered a step-by-step scheme for energy supply of a large facility, using the example of the Kerch bridge, and made an analysis of the potential usage of hybrid power plants based on renewable energy sources for the implementation of projects. We developed methodological approaches to the implementation of large-scale projects that would allow one to take into account not only economic efficiency, but all the positive effects that can be achieved from the project.
\end{abstract}

\section{Introduction}

Nowadays large-scale projects using various energy-supply schemes are actively implemented in Russia and in a number of foreign countries. The statistics shows that there are many problems related to efficiency and reliability of energy supply (including that using alternative energy sources) of large transport objects, including bridges [1-13].

In 2018 the "Dal'nevostochnaya energeticheskaya kompaniya" (DEK) taking into account the $3.8 \mathrm{mln}$ rubles debt of "Tihookeanskaya mostostroitel'naya kompaniya" (TMK) limited the electrical power supply of the Zolotoy most at Vladivostok and the Narvinskiy tonnel being built at Khasanskiy district of Primor'e [14]. The Republic of Karelia is one of the most problematic regions of the Northwestern Federal District (NWFD), where power outages occur frequently. It can be set as an example for illustrating another one significant problem, which is common for many regions, especially that of the Arctic territory. At the Republic electrical lines are rather often with dead end feeder, not looped. In order to provide reliable energy supply of the region one should put these lines on a loop, which appears to be unreasonably expensive for the region with the average population density of 3.5 people per sq $\mathrm{m}$. As an alternative way one may use diesel power plants, but it is expensive too.

\footnotetext{
*Corresponding author: novikova-olga1970@yandex.ru
} 
During our investigation we studied research works of the Russian scientists in the field of renewable power engineering: E.L. Akim, P.P. Bezrukikh, V.V. Bushuev, V.I. Vel'kin, Gorbunova T.Yu.,T.S. Khachaturova, Yu.A. Tsetserin, Belyaev Yu.M., Serebryakov R.A. Popel O.S., Fedorov M.P., Elistratov V.V., etc.

\section{Materials and methods}

Theoretical and methodological basis of the research are the works of domestic and foreign scientists in the field of environmental management, energy efficiency and resource saving, sustainable development, strategic management. The work used methodological and regulatory legal sources in the sphere of state regulation of energy-efficient development of socio-economic systems. The research methodology is based on such scientific methods as: comparative analysis, statistical and graphical methods.

\section{Results and analysis}

Renewable energy sources (RES) would make it possible to move to a fundamentally new level of high-quality and uninterrupted power supply of large infrastructure facilities, taking into account the reliability categories [15-17]. The provision of large objects of social infrastructure with electricity, produced on the basis of renewable energy sources, can become a priority in the implementation of the energy development strategy of Russia for the period up to 2030 [18].

The object of the study is the efficiency of supplying large transport infrastructure projects with electricity.

The subject of the study is the use of RES on the objects of transport infrastructure.

The aim of the study is formation of methodical approaches to electricity supply using RES on the objects of transport infrastructure.

The result of research is the formed methodical approach to the implementation of large-scale projects of electricity supply of the transport infrastructure.

The economic efficiency of implementing RES renewable energy projects should not be considered separately, but should be considered within the framework of a methodical approach developed for a specific regional project, since this approach gives an objective idea of the feasibility of implementing the project under consideration using renewable energy sources and gives an understanding of the positive effects which can be achieved both for the region, and for the country as a whole.

An additional socially significant effect of this approach is the activation of research activities, especially in local areas, which are close to the projects territorially. Such research centers could be universities that can develop and conduct direct measurements at the stage of pre-project design. 51 from 74 regions of Russia are suffering from power shortages.

The most expensive electrical energy at the territory of the Russian Federation is at FarEast and Siberian Federal districts [19].

The additional capacity should be planned taking into account requirements of prospective development, reliability, economical and ecological efficiency of the project as a whole.

For majority of the large-scale projects, such as transport interchanges in Sochi, the Western High-Speed Diameter road in Saint-Petersburg, the stadium "Saint-Petersburg" and the transport bypass through the Kerch strait, the 3 stages can be pointed out (without EAD taking into account) [20]: The object construction, test exploitation of the object with further finishing construction, complete commissioning of the object. 
1 - Construction stage: includes construction of the necessary infrastructure, such as: residential premises, access roads, construction sites, storage facilities, electrification of construction sites and other necessary infrastructure objects. This stage is characterized by the highest consumption of electrical energy $(\approx 300 \%$ from consumption at the 3 rd stage (project)). In the majority cases the required reliability of electricity collectors is not higher than the 3 category [18].

For the period of construction of the Kerch bridge the variant with connection to main circuits and diesel-driven generator installation at consumers was chosen (for the 1 st and the 2nd categories). Namely, construction of electrical station ES 110/35/10, 2x electrical stations ES 35/10, packaged transformer substation $10 \mathrm{kV}, \mathrm{HV}$ line $110 \mathrm{kV}$, aerial cable line $35 \mathrm{kV}$, cable line $10 \mathrm{kV}$.

2 - The stage for test commissioning means partial commissioning of the object. This stage is characterized by the similar electrical energy consumption $(\approx 150-300 \%)$, as a part of construction works are completed. So the consumption of construction decreases, but there appear electrical loads of the object.

In most of the cases the required reliability of the electrical receivers is the 1st and 2nd categories. For feeding of consumers of the 1st special category the diesel-driven generators with autorun or an uninterruptible power supply unit (UPS) are usually installed individually or per a consumer group.

For the Kerch bridge one may identify 2 stages: Test commissioning of the motor road bridge (2018); Test commissioning of the railroad bridge (2019).

3 - The stage of commissioning is characterized by the designed consumption of electrical energy. In most cases the required reliability of the electrical receivers is of the 1 st and 3rd stages.

\subsection{Variants of the electrical supply}

While designing the power supply one should calculate the electrical loads for the all 3 stages. Further, one should select not less than 2 sources of electrical energy.

Use of connection to mail lines or regional lines is often difficult or impossible due to: the absence of free capacities, connection points, or obtaining of specifications only for the 3rd category of the reliability.

So, it is viable to consider the following possibilities:

- Alternative energetics with main or regional lines;

- Alternative energetics with self-generation;

- $\quad$ Alternative energetics with DDG or UPS.

Usage of alternative energetics with main or regional networks appears to be the most winning variant.

Alternative energetics based on RES will allow one to provide electrical energy to the objects, related to the 3rd category of the electrical receiver according to the Rules of Electrical Facilities Maintenance (7th Edition), and to partly provide electrical energy at the early stages of the construction. This approach will allow one to reduce expenses at all 3 stages. It is viable to establish the generation based on the total power calculation for the exploitation period. Thereby we will minimize the expenses, namely, reduce the consumption of electrical energy from the external mains and reduce the cost of connection to external electrical lines (this is because we will request Specifications for the 1st and 2nd categories of reliability, not for the $3 \mathrm{rd}$ one). The suggested consumption structure is presented in Table 1.

Table 1. Consumption structure at usage of RES sources and external networks

Consumption from $\quad$ Consumption from external networks




\begin{tabular}{|l|c|l|}
\hline Construction & RES sources & \\
\hline Test exploitation & Up to $75 \%$ & $\begin{array}{l}60-70 \%+\text { reservation of consumers of the 1st } \\
\text { and 2nd categories }\end{array}$ \\
\hline Exploitation & $100 \%$ & $\begin{array}{l}\text { Just reservation of consumers of the 1st and } \\
\text { and 2nd categories } \\
\text { 2nd categories }\end{array}$ \\
\hline
\end{tabular}

For this moment there exist 3 main types of projects which use the energy units based on RES: combined connection with AC bus, combined connection with DC bus and combined mixed connection AC/DC. Each connection type is considered with calculation of efficiency of the consumed power from each power source directly or through an accumulator battery. This is aimed at comparison of various types of the combined schemes of electric supply and efficiency improvement. The results are used for making conclusions concerning the energy setup efficiency, as well as its advantages over traditional energysupply sources.

For feeding the Kerch bridge the most viable variant was to use RES together with main or regional networks. Annual specific operating capacity of the wind energy at the Republic of Crimea is from 2490 to $3820 \mathrm{MW} \cdot \mathrm{h} /$ year [20].

For the construction period one had to install 7 wind turbines of $1 \mathrm{MW}$ capacity at the bar or the island of Tuzla. And connection of one $110 \mathrm{kV}$ line from the ES Volna with construction of ES $110 / 20 \mathrm{kV}$ and a $20 \mathrm{kV}$ distribution system (taking into account the electrical loads and the length of the object one should abandon 10 and $35 \mathrm{kV}$ potential in favour of $20 \mathrm{kV}$ ). So, during the exploitation period the wind-turbine energy was the basic one, and the power from ES was on reserve during the construction stage. Consumption structure using the example of the Kerch bridge construction is presented in Table 2.

Table 2. Consumption structure using the example of the Kerch bridge

\begin{tabular}{|l|c|l|}
\hline & $\begin{array}{c}\text { Consumption from } \\
\text { RES sources }\end{array}$ & \multicolumn{1}{|c|}{ Consumption from external networks } \\
\hline Construction & 37.8 & $\begin{array}{l}62.2 \%+\text { reservation of consumers of the 1st } \\
\text { and 2nd categories }\end{array}$ \\
\hline $\begin{array}{l}\text { Test exploitation of } \\
\text { the motor road } \\
\text { bridge }\end{array}$ & $41.1 \%$ & $\begin{array}{l}58.9 \%+\text { reservation of consumers of the } 1 \mathrm{st} \\
\text { and } 2 \text { nd categories }\end{array}$ \\
\hline $\begin{array}{l}\text { Test exploitation } \\
\text { with finishing } \\
\text { construction }\end{array}$ & $59.3 \%$ & $\begin{array}{l}49.7 \%+\text { reservation of consumers of the } 1 \mathrm{st} \\
\text { and } 2 \text { nd categories }\end{array}$ \\
\hline Exploitation & $100 \%$ & $\begin{array}{l}\text { Just reservation of consumers of the } 1 \mathrm{st} \text { and } \\
\text { 2nd categories }\end{array}$ \\
\hline
\end{tabular}

Despite the long-lasting payback period of the RES, there are some advantages of combined power stations: non-depletability of the RES, possibility to use combined power stations at the technically-isolated regions, cost reduction of electric energy, reduction of losses at the network, environmental friendliness, assistance of evolution of other economic sectors. 


\section{Conclusions}

The authors have developed a methodological approach to realization of the similar largescale socially-important objects such as the Kerch bridge in order to improve attractiveness of the combined power station technologies, which is presented in Table 3.

Table 3. Methodological approach to realization of the large-scale projects

\begin{tabular}{|c|c|c|}
\hline Stage & Description of the stage & The achieved outcome \\
\hline $\begin{array}{l}\text { Preliminary assessment of } \\
\text { RES potential of the region }\end{array}$ & $\begin{array}{l}\text { Hydrometeorological } \\
\text { examination, estimation of } \\
\text { the RES point potential }\end{array}$ & $\begin{array}{l}\text { Involvement of the research } \\
\text { institutions to the works, } \\
\text { creation of new educational } \\
\text { directions and workplaces }\end{array}$ \\
\hline $\begin{array}{l}\text { Analysis of the industry } \\
\text { structure of the region and } \\
\text { development of RES } \\
\text { development programs in } \\
\text { the region }\end{array}$ & $\begin{array}{l}\text { Assessment of the efficiency } \\
\text { of strategy and energy } \\
\text { politics, } \\
\text { implementation of the RES } \\
\text { in the large-scale regional } \\
\text { projects }\end{array}$ & $\begin{array}{l}\text { Development of the regional } \\
\text { laws for RES: invention of } \\
\text { models, techniques and } \\
\text { algorithms for assistance for } \\
\text { RES development in the } \\
\text { region }\end{array}$ \\
\hline $\begin{array}{l}\text { Implementation of the } \\
\text { regional projects using RES }\end{array}$ & $\begin{array}{l}\text { Choice of combined power } \\
\text { station variants and the } \\
\text { project implementation } \\
\text { using the RES, electrical } \\
\text { energy supply to the line, } \\
\text { reduction of energy poverty } \\
\text { (if the region is a part of the } \\
\text { Russian United Energy } \\
\text { System). }\end{array}$ & $\begin{array}{l}\text { Improvement of the energy- } \\
\text { system reliability, } \\
\text { satisfaction the demand for } \\
\text { electrical energy, reduction } \\
\text { of kWh cost (especially at } \\
\text { the energy-isolated regions); } \\
\text { Evolution of the } \\
\text { accompanying branches, } \\
\text { invention of the principally } \\
\text { new electrical-energy } \\
\text { setups, communication and } \\
\text { monitoring systems. }\end{array}$ \\
\hline
\end{tabular}

Economic efficiency of the combined power station projects based on RES implementation shouldn't be considered separately, but should be considered in a framework of the developed methodological approach for a certain regional project. This is because this approach gives an objective assessment the feasibility of the considered project with the RES usage and gives an understanding concerning the achieved positive effects both for the region and the country as a whole.

An additional socially important effect at this approach is of activation of the research activity, especially in local areas, which are territorially close to the projects. The universities might become such research centers, which will be able to make inventions and carry out the directed measurements at the pre-project design stage.

\section{References}

1. V.V. Elistratov, I.G. Kudryasheva, ARPN Journal of Engineering and Applied Sciences 2016, 3509-3512 (2016)

2. A. Sablina, V. Dubolazov, MATEC Web of Conferences 170, 05002 (2018)

3. V.V. Elistratov, A.V. Vinogradova (Chernova), International Journal of Hydrogen Energy 42(17), 12355-12363 (2017) 
4. V.V. Potekhin, D.N. Pantyukhov, D.V. Mikheev, EAI Endorsed Transactions on Energy Web 17(11), e5 (2017)

5. L.D. Khabachev, U.I. Plotkina, T.M. Bugaeva, A.B. Yurkova, ICRITO 2017, 188-193 (2018)

6. M. Zubkova, A. Stroganov, A. Chusov, D. Molodtsov, Key Engineering Materials 723 KEM, 616-621 (2017)

7. I. Konstantinov, A. Savchenko, A. Frolov, L. Akimov, M. Holmin, M., MATEC Web of Conferences 53, 01064 (2016)

8. A. Fedyukhin, I. Sultanguzin, A. Gyul'Maliev, V. Sergeev, Eurasian ChemicoTechnological Journal 19(3), 245-253 (2017)

9. V. Elistratov, M. Konischev, M. Fedorov, ICIEAM 2017 - Proceedings 8076220 (2017)

10. V. Maslikov, E. Negulyaeva, A. Cheremisin, A. Chusov, D. Molodtsov, A. Stroganov Solid State Phenomena 871, 199-207 (2016)

11. N. Arefiev, O. Nikonova, N. Badenko, T. Ivanov, V. Oleshko, Vide. Tehnologija. Resursi - Environment, Technology, Resources 2, 41-50 (2015)

12. A. Asadpoori, C. Ankomah, A. Asadpoori, O. Derevianko, E. Shaburov, MATEC Web of Conferences 193, 02039 (2018)

13. N.A. Politaeva, T.A. Kuznetsova, Y.A. Smyatskaya, E.V. Trukhina, I. Atamanyuk, Chemical and Petroleum Engineering 53(11-12), 801-805 (2018)

14. The bridge Zolotoy and the Narvin tunnel in Primorski Krai have been left without power for the debts. [Online] Available : https: https://ria.ru/economy/20150317/1052910180.html (date: 20.07.2018)

15. Elistratov V.V. , Publ house of the Poytechnical University, 417 (2016)

16. Apergis N., Payne J. E. , Energy Policy. Vol. 38. Iss. 1. P. 656-660 (2010)

17. Global Trends in Renewable Energy Investment 2015. Bloomberg New Energy [Online] Available : http://fs-unep-centre.org/publications/global-trends-renewableenergy-investment-2015

18. Moscow School of Management Skolkovo. Usage of the distributed energy potential for development of the electrical energy of Russia [Online] Available : https: https://energy.skolkovo.ru/downloads/documents/SEneC/News/SKOLKOVO_EneC_2 017.11.01_Khokhlov.pdf (date: 15.07.2018)

19. Region rating according to the energy sufficiency - 2017 [Online] Available : https: http://vid1.rian.ru/ig/ratings/energodeficit012018.pdf (date 16.07.2018)

20. Gorbunova T.Yu. "State of knowledge for the wing power engineering of the Crimea peninsula" [Online] Available : https: http://geo.asu.edu.ru/files/3(66)/147-161.pdf (date: 20.07.2018) 